\title{
STANJE RAZISKANOSTI CERKVENE GLASBENE DEJAVNOSTI NA SLOVENSKEM V DRUGI POLOVICI 18. IN ZAČETKU 19. STOLETJA
}

\author{
RADOVAN ŠKRJANC \\ Znanstvenoraziskovalni center SAZU
}

\begin{abstract}
Izvleček: Prispevek je zgoščen pregled stanja raziskanosti različnih področij cerkvenoglasbene dejavnosti na tleh današnje Republike Slovenije v obdobju druge polovice 18. in začetku 19. stoletja. V prispevku so še na kratko analizirane glavne poteze dveh precej različnih načinov dosedanje zgodovinske interpretacije te dejavnosti, kot ju vsebujeta oba pomembnejša orisa zgodovine glasbe na Slovenskem, D. Cvetka in J. Höflerja. Podana sta tudi nabor potrebnih nalog, ki čakajo prihodnje preučevanje tega dela glasbene preteklosti pri nas, ter izbor relevantne domače in tuje (muzikološke) literature o njem, objavljene po letu 1950.
\end{abstract}

Ključne besede: cerkvena glasba, glasba druge pol. 18. in začetka 19. stoletja, zgodovina glasbe na Slovenskem, glasbenozgodovinopisne interpretacije
Abstract: This paper contains a brief overview of the present state of research on various aspects of sacred music in Slovenia from the second half of the eighteenth century and the beginning of the nineteenth century. It also deals (concisely, but thoroughly) with some principal features of two rather different approaches to historical interpretation of these activities, as they appear in the two most important outlines of musical history in Slovenia to date: those by Dragotin Cvetko and Janez Höfler. In addition, the paper addresses some tasks required for future investigation of this part of Slovenian music history and presents the bibliography of selected musicological literature published after 1950, which is relevant for this study.

Keywords: sacred music, music from the mideighteenth to the beginning of the nineteenth century, history of music in Slovenia, interpretations of music history

Obseg dosedanjih raziskav cerkvene glasbene dejavnosti pri nas v drugi polovici 18. in prvih desetletij 19. stoletja je razmeroma velik, vsaj v primerjavi z več drugimi, nič manj pomembnimi segmenti glasbenega življenja na Slovenskem iz tega časa. To kaže že razmerje med številom - bodisi objavljenih bodisi (̌̌e) ne objavljenih - prispevkov o cerkveni in posvetni glasbeni dejavnosti pri nas v tem obdobju (predvsem klavirski, komorni in glasbeno-pedagoški, pa tudi simfonični izven kroga delovanja ljubljanske Filharmonične družbe od konca devetdesetih let 18. stoletja dalje), ki je v resnici le odsev razmerja med obsegom dosedanjega preučevanja virov za cerkveno glasbo na eni in posvetno glasbo tistega obdobja na drugi strani (z izjemo opere). Razlog za to je deloma boljša ohranjenost 
arhivskega gradiva za študij cerkvene glasbe oziroma cerkvenoglasbenega življenja tedaj pri nas, bodisi da gre za ohranjenost muzikalij v arhivih pri različnih cerkvah in samostanih v Sloveniji ali pa za ohranjenost sekundarnih virov v zvezi s tem, npr. v Nadškofijskem arhivu v Ljubljani.

Četudi dosti manj, je omenjeno razmerje vendarle tudi odraz samega pristopa k preučevanju glasbene preteklosti iz tega obdobja pri nas, ki je dalj časa prevladoval v domači muzikološki stroki in je vsaj v osnovi izhajal iz prvega bolj poglobljenega orisa tudi te preteklosti v delih Dragotina Cvetka, izdanih že v petdesetih in šestdesetih letih prejšnjega stoletja. Posebno vplivna v tem pogledu je bila seveda Cvetkova Zgodovina glasbene umetnosti na Slovenskem v treh delih, kot eden odločilnih in v resnici kolosalnih temeljev za prihodnje raziskovanje slovenske zgodovine glasbe in nasploh za razvoj domače muzikologije kot širše umeščenega področja znanosti, ki pa je to zgodovino - kolikor neposredneje je sledilo tej osnovi, toliko bolj - umevalo posploševalno v smislu epohnoslogovnega koncepta zgodovine; zato - tj. zaradi principa generalizacije kot osnovnega vodila pri tovrstnem urejanju partikul iz preučevane glasbene preteklosti v razmeroma doumljiv pogled nanjo, pač »po logiki« zeitgeista - je lahko zgodovino glasbene umetnost na Slovenskem v znatni meri obravnavalo le »skozi« zgodovino glasbe nekdanje Kranjske ali celo samo Ljubljane, ter takšno zgodovino (nato) deklariralo za »vseslovensko«. Odločilni del arhivskih virov za raziskovanje komorne, simfonične in klavirske glasbe, pa tudi glasbene didaktike na sredini in v drugi polovici 18. stoletja je namreč razen v NUK ohranjen pri nas vsaj še v Novem mestu in na Ptuju. Ne glede na to pa ti viri še do nedavnega, kljub njihovemu popisu že $\mathrm{v}$ šestdesetih letih prejšnjega stoletja in z izjemo spisov Janeza Höflerja, ki je ta popis tudi opravil, niso uživali tolikšne pozornosti kot pa denimo viri za preučevanje glasbene dejavnosti po cerkvah v Ljubljani, med njimi v prvi vrsti stolnice, in iz poznejšega časa viri za preučevanje ljubljanske Filharmonične družbe.

Takšen »ljubljanocentrizem« je po eni strani načeloma nasprotujoč sicer nikjer eksplicitno omenjeni, a v Cvetkovem pisanju vseeno precej nedvoumno odmevajoči ideji »kulturnobojnega« dokazovanja: v prvi vrsti samega zgodovinskega obstoja glasbene umetnosti na Slovenskem, njene pripadnosti evropskemu kulturnemu miljeju ter slogovne primerljivosti, vsaj latentno pa tudi »nič-manjše-vrednosti« nasproti - bolj abstraktno zamišljeni - evropski glasbi in - mestoma tudi povsem konkretno izpostavljeni - nemški glasbi. V ozadju tega je bila avtorjeva implicitna težnja po relativiziranju znanih in za glasbene kulture »na obrobju« (H. H. Eggebrecht) bolečih vrednostnih paradigem glede razmerja med glasbo na periferiji in v večjih evropskih centrih ter nemško in ne-nemško glasbo vsaj od J. S. Bacha dalje (kar seveda še posebej velja za obravnavo glasbene preteklosti na območju sedanje Slovenije). ${ }^{1}$ Obe paradigmi sta hkrati eden od »nosilnih stebrov« sistema epohno-slogovne zgodovine glasbe t.i. tradicionalne nemške historiografije, normativno osrediščene s hegeljanskim pojmom klasicizma, ki ji je pod vplivom zlasti Adlerjevega zgodovinopisja sledila tudi glasbena historiografija D. Cvetka, v marsičem paradoksalno: kot že rečeno, tudi s fokusiranjem zgodovine glasbe na Slovenskem v

1 Prim. Hans Heinrich Eggebrecht, Musik im Abendland, München, Zürich, Piper, 1991; Vladimir Karbusicky, Wie Deutsch ist das Abendland? Geschichtliches Sendungsbewußtsein im Spiegel der Musik, Hamburg, Bockel, 1995, str. 44-45. 
glasbeno preteklost najpogosteje le ljubljanskega območja, kar je - po drugi strani - zopet mogoče delno pojasniti kot svojevrstno principialno skladnost z vodiloma selekcije in vzorčenja v sistemu epohno-slogovnega zgodovinopisja. ${ }^{2}$

Povedano nakazujejo že naslovi nekaterih pomembnejših Cvetkovih del, kot sta Južni Slovani v zgodovini evropske glasbe iz leta 1981 (nemška verzija je izšla že leta 1975) in desetletje mlajša knjiga Slovenska glasba v evropskem okviru, ${ }^{3}$ ki jo lahko razumemo kot sižé Cvetkovega v resnici fascinantnega opusa na področju zgodovine glasbe na Slovenskem; še bolj pa povedano potrjuje na primer dejstvo, da niti v tem najmlajšem Cvetkovem povzetju glasbene preteklosti pri nas (iz leta 1991) niso upoštevana nekatera v resnici težko zanemarljiva dejstva glede cerkvene glasbene dejavnosti v Sloveniji iz druge polovice 18. in začetka 19. stoletja. Tako v njem niso niti omenjeni skladatelji kot so Egidij Schenk (ki je med letoma 1764 in 1767 deloval na Ptuju, sicer pa je bil graški kapelnik in eden vodilnih glasbenikov tedanje Štajerske), Franz Kubik (kapelnik goriške stolnice v 1. polovici 19. stoletja; večje število njegovih cerkvenih del je danes ohranjenih tudi v Novem mestu in v Ljubljani), ${ }^{4}$ Giacomo Genzo (koprski stolni organist v 1. polovici 19. stoletja in skladatelj več motetov, ofertorijev in maš, med katerimi sta vsaj dve večjega obsega), Rafael Illowsky (skladatelj cerkvene glasbe in nasploh glasbeno zelo dejaven frančiškan v Kostanjevici pri Gorici v 1. polovici 19. stoletja), Peter Černivan (zanimiv sodobnik J. F. Zupana in skladatelj cerkvene glasbe v Kopru) ${ }^{5}$ ter Valentin Lechner (ki je deloval v mariborski stolnici do leta 1805, ko je v Celovcu prevzel mesto organista pri sv. Egidiju, in od katerega se je pri nas ohranilo vsaj deset rokopisov cerkvenih del, med njimi tudi nekaj velikopoteznejših). Ne samo torej, da navedeno Cvetkovo delo kar na splošno spregleduje delo nekaterih pomembnejših središč cerkvene glasbe v tem obdobju, ki so bila sicer že takrat »na obrobju« slovenskega etničnega prostora, a so bila z njim vseeno tudi tesneje povezana (zlasti Gorica); iz Cvetkovega orisa cerkvene glasbe na Slovenskem v drugi polovici 18. in na začetku 19. stoletja je skoraj povsem izvzeto tudi delo dveh središč na tleh današnje Republike Slovenije (v Kopru in Mariboru), za kateri so že vsaj od konca šestdesetih let prejšnjega stoletja znani številni podatki, ki so nepogrešljivi za podrobnejši, predvsem pa celovit uvid v zgodovino cerkvene glasbe pri nas.

Takšno izvzetje celega dela glasbene preteklosti pri nas iz sodobnega zgodovinskega ukvarjanja z njo je v resnici zelo presenetljivo. Še najbolj seveda zaradi objave precejšnjega

2 Podrobneje o tem: Radovan Škrjanc, 'Stylus rusticanus' v cerkveni glasbi na Slovenskem od sredine 18. do sredine 19. stoletja, Ljubljana 2008 (Univerza v Ljubljani, Filozofska fakulteta, doktorska disertacija), str. 1-170.

3 Prim. Dragotin Cvetko, Slovenska glasba v evropskem okviru, Ljubljana, Slovenska matica, 1991, »Predgovor«.

4 Skladatelja F. Kubika Cvetko sicer omenja v drugi knjigi Zgodovine glasbene umetnosti na Slovenskem (izdani leta 1959), vendar le med naštetjem kandidatov, ki so se leta 1816 prijavili na razpis za učitelja v Javni glasbeni šoli v Ljubljani.

5 Pri pregledu notnega gradiva v Škofijskem arhivu v Kopru leta 2006 se je izkazalo, da so muzikalije Petra Černivana, ki jih omenja Höfler, pogrešane (Janez Höfler, Tokovi glasbene kulture na Slovenskem od začetkov do 19. stoletja, Ljubljana, Mladinska knjiga, 1970, str. 115). Zadnje objavljeno delo, ki še potrjuje obstoj izvirnikov s skladbami tega skladatelja v Kopru, je: Giuseppe Radole, La musica a Capodistria, Trst, Centro studi storico-religiosi Friuli-Venezeia Giulia, 1990, str. 61. 
števila omenjenih podatkov že v Höflerjevi knjigi Tokovi glasbene kulture na Slovenskem od začetkov do 19. stoletja iz leta 1970, ki je drugi in do sedaj še ne preseženi mejnik v domačem glasbenem zgodovinopisju na ravni razmeroma zgoščenega kumulativnega pregleda zgodovine glasbe v slovenskem kulturnem prostoru do okoli leta 1850 . Od izida knjige letos mineva že celih štirideset let, kar nenazadnje še dodatno pritrjuje mnenju, da je prav umanjkanje Höflerjevih raziskav cerkvene glasbe v Sloveniji iz obdobja 18. in začetka 19. stoletja po približno letu 1980 obenem pomenilo tudi večletno stagnacijo pri širitvi neke poglobljene vednosti o tem delu slovenske glasbene preteklosti, bodisi na ravni poznavanja kompozicijskega ustroja različnih praks cerkvene glasbe tedaj pri nas bodisi na ravni odkrivanja novih (»sekundarnih«) informacij v zvezi z njimi. Oboje je nadaljevala mlajša generacija muzikologov šele od sredine devetdesetih let prejšnjega stoletja dalje s preučevanjem cerkvenih del V. Wratnyja (Aleš Nagode), F. L. Schwerdta (Zoran Krstulović) in J. F. Zupana (Radovan Škrjanc).

Nasploh so raziskave domače cerkvene glasbene dejavnosti, ki jih je zlasti v šestdesetih in deloma sedemdesetih letih prejšnjega stoletja opravil Janez Höfler, priskrbele veliko novih informacij o tej dejavnosti v drugi polovici 18. in prvi polovici 19. stoletja, ki so hkrati tudi na široko odprle pot prihodnjemu raziskovanju. Podobno velja za drugi, nič manj pomemben dosežek Höflerjevih Tokov na področju preučevanja omenjene dejavnosti. Gre namreč za opaznejši pomik naprej ne le v razširitvi in natančnosti dotedanjega védenja, temveč tudi v načinu interpretiranja oziroma zgodovinopisnega opredeljevanja že znanih zgodovinskih dejstev, ki ga ta knjiga vsebuje, kar zopet nakazuje vsaj potrebo po še nadaljnjem spreminjanju perspektive v današnjem pogledu nanje. Kajti tudi Tokovi domačo cerkveno glasbeno dejavnost iz 18. in prve polovice 19. stoletja po eni strani še vedno periodizirajo $\mathrm{v}$ tri splošna umetnostnozgodovinska obdobja: barok, klasicizem in - terminološko zelo vprašljivo - obdobje razsvetljenstva. Po drugi strani pa tedanje stanje cerkvene glasbe pri nas središčijo z vrednostno privilegiranim (slogovnim) pojmom dunajskega klasicizma - bodisi eksplicitno ${ }^{6}$ bodisi implicitno: $:^{7}$ kljub temu, da avtor sam (v uvodu knjige, napisanem že jeseni leta 1968) pojasnjuje dvom v to vrsto pisanja zgodovine glasbe na Slovenskem, vsaj za starejša obdobja do 19. stoletja, ko pravi, da njegovo delo »bolj ali manj ohranja tip kulturne zgodovine s področja glasbene umetnosti in ni uvod v slogovno zgodovino slovenske glasbe: tej je mogoče slediti pozno, šele v 19. stoletju«. Zaradi tega svojega dela, kot še pravi, tudi ni »poimenoval kot 'zgodovino', temveč [je] z naslovom hotel poudariti, da [je v njem] obravnaval le tokove in oblike glasbene kulture pri nas v časovno določenih obdobjih, ki s svojimi zunanjimi (in ne notranjimi slogovnimi) značilnostmi kažejo na ustrezna slogovna obdobja evropske glasbene zgodovine«.

${ }^{6}$ V Tokovih Höfler denimo skladateljske opuse »Schiedermayrja, Eyblerja in Seyfrieda, ki so bili [...] zastopani tudi na korih slovenskih mestnih cerkva, čeprav Haydnove veličine«, kot še pravi, »ob vsem svojem obsežnem opusu niso mogli doseči«, stavi v okvir »avstrijskih epigonov dunajske klasike«. Nav. delo, str. 132.

7 Za uveljavljanje glasbenega klasicizma na slovenskih tleh pa Höfler pravi, prav tako v Tokovih, da se je ta »mogel [...] razširiti [...] prej in laže kot likovni [klasicizem]. Razumljivo je tudi, da se je [glasbeni klasicizem pri nas] izrazil na nižji in poljudnejši ravni« kot pa »visoki klasicizem, ki je nastopil z dunajsko klasiko, s Haydnom, Mozartom, in se nadaljeval pri mladem Beethovnu [ter] dosegel idealni vrh razvoja«. Nav. delo, str. 127-128. 
Poleg dvoma v ustreznost neposredne slogovne primerjave domače glasbene kulture z značilnostmi slogovnih epoh evropske glasbene zgodovine, ki ga je mogoče brez težav teoretično vzporediti z razlikovanjem med videzom in strukturo v francoskem zgodovinopisju predvsem iz šestdesetih let prejšnjega stoletja, pa Höfler sam - vsaj posredno in ravno v uvodnem delu poglavja o dosežkih kompozicijskega ustvarjanja pri nas v »obdobju klasicizma« - izraža tudi dvom v ustreznost, kot pravi, pavšaliziranja občutljivega umetnostnorazvojnega poteka klasicizma oziroma neoklasicizma v 17. in 18. stoletju širom po Evropi, ki je temeljil v posebnih družbenih razmerah zahodne Evrope, in sicer tako na ravni geografskih razlik (Francija - Srednja Evropa oz. Avstrija) kot tudi na ravni različnih umetnostih področij (likovna umetnost - glasba). ${ }^{8}$ To seveda že samo po sebi in načeloma odpira možnost precej drugačne razdelitve razmeroma enovito zamišljenih slogovno-umetniških obdobij v epohno-slogovni zgodovini umetnosti oziroma glasbe kot nekakšnega podsistema te umetnosti, pač »po hegeljanski logiki« zeitgeista, kot pa je (bila) omenjena obdobja pripravljena notranje strukturirati te vrste zgodovina. Ali bolj konkretno: ko namreč Höfler v Tokovih po eni strani »parcelira« celotno območje glasbene dejavnosti pri nas v obdobjih razsvetljenstva in klasicizma v razmeroma samostojna in samosvoja področja te dejavnosti tudi znotraj cerkvenoglasbenega področja kot specifičnega dela nasproti koncertni in operni dejavnosti; ko delovanju ljubljanske stolne kapele namenja približno enako mero pozornosti kot glasbenemu delu na podeželju oziroma slovenski cerkveni pesmi 18. in 19. stoletja; ko tudi glasbeno ustvarjanje posameznih skladateljev (Wratnyja, Schwerdta, Hölerja, G. Maška) deli na dve »strani«, različni po socialni funkciji in posledično glasbeni strukturi (slovesnejša cerkvena glasba - porabna cerkvena glasba, ki je »druga stran cerkvenega glasbenega ustvarjanja«); ko za slogovno opredeljevanje (vsaj dela) tedanje cerkvene glasbene tvornosti pri nas uvaja pojem klasicizma »na nižji, poljudnejši ravni«; ali ko denimo preprostost in ljudski prizvok Zupanovih cerkvenih skladb eksplicitno postavlja na začetek posebnega »okvira« oziroma posebne tradicije slovenske cerkvene glasbe, ki sta jo nato nadaljevala zlasti Schwerdt in Rihar ... - vse to $\mathrm{v}$ resnici že pomeni tudi načelni odmik od zgoraj omenjenega principa generalizacije in obenem približevanje tisti vrsti partikularizacije zgodovine, ki jo je predvsem starejša generacija zgodovinarjev očitala denimo Foucaultovemu predlogu zgodovine kot arheologije relativno samosvojih praks pretekle človekove dejavnosti, in kot jo potencialno ponujajo tudi nekatera nekoliko mlajša teoretična stališča, zbrana v pojmih kulturna praksa P. Bourdieuja in materialna socialna praksa Bruca Hornerja, ki izhaja iz nazorov t.i. kulturnega materializma angleškega marksista Raymonda Williamsa.

Vsekakor je takšen Höflerjev »kulturnozgodovinski« odmik »iz okvirov« Cvetkove interpretacije zgodovine ( $\mathrm{k}$ relativno enakovredni obravnavi različnih tokov in oblik glasbene kulture pri nas v časovno določenih obdobjih - torej tudi ko gre za obravnavo cerkvene glasbe v Sloveniji iz druge polovice 18. in začetka 19. stoletja) ne samo občudovanja vredno podjetje že zaradi svoje naprednosti celo v primerjavi z znamenito Foucaltovo utemeljitvijo »nove zgodovine « iz leta $1969,{ }^{9}$ temveč je danes lahko tudi edino

8 J. Höfler, nav. delo, str. 126-129.

9 Prim. Michel Foucault, Arheologija vednosti [prev. dela L'archéologie du savoir, Pariz 1969], prev. Uroš Grilc, Studia humanitatis 165, Ljubljana 2001. 
ustrezno konceptualno izhodišče za naprej. Kajti le nadaljnje še podrobnejše preučevanje celega spektra različnih modusov funkcioniranja cerkvene glasbene dejavnosti pri nas v tem obdobju, in sicer brez vsakršnih vrednostnih predsodkov do enega ali drugega načina oziroma brez vsakršnega estetskega »absolutiziranja« ali idealiziranja katerega med njimi - kar seveda zahteva še nadaljnji odmik tudi od prej omenjenih Höflerjevih stališč v zvezi s pojmom dunajskega klasicizma -, je lahko edino, kar vodi k »višji stopnji« védenja o neki razmeroma posebni zgodovinski situaciji pri nas na področju cerkvene glasbe v času 18. in 19. stoletja, in kar lahko posledično osmisli tudi pisanje načrtovane »nove zgodovine glasbe na Slovenskem«. Preučevanje denimo samo svečanih maš Schwerdta in Wratnyja je seveda nujno in pomembno, a še nezadostno za natančnejše poznavanje stanja cerkvene glasbe na naših tleh v tem obdobju, ko je - kot že rečeno - ne le obstajala, temveč v marsičem celo prevladovala ravno »druga stran cerkvenega glasbenega ustvarjanja«, ki pa je (bila) v dosedanjih raziskavah domače glasbe žal le redko ustrezno upoštevana.

Zato se tej, »drugi strani« cerkvenega glasbenega ustvarjanja pri nas velja v prihodnje veliko bolj pozorno posvetiti. In sicer tako v obliki posebnih študij kot tudi s primerjavo te »strani« z »od nje drugačno«, ali z ugotavljanjem strukturnega odnosa med takšno glasbo in v resnici več »stranmi« omenjenega ustvarjanja takrat pri nas, ki poleg ruralne in »ne-ruralne strani« oziroma »področja [...] porabne cerkvene glasbe [...] za podeželje« na eni ter »velike vokalno-instrumentalne slovesne maše « na drugi strani (J. Höfler) obsega še razmeroma posebne prakse, kot je bila praksa komponiranja frančiškanske glasbe, cerkveno-pesmariškega repertoarja, prirejanja operne glasbe za izvajanje z bogoslužnim besedilom v cerkvah (t.i. kontrafakture), praksa naknadnega orkestriranja izvirno vokalne cerkvene glasbe s spremljavo orgel (kot jo kažejo na primer separati godal in trobil s pisavo p. Rafaela Illowskega, pozneje dodani več starejšim skladbam v novomeškem frančiškanskem samostanu) in dodajanja instrumentalnih glasov k že instrumentiranim cerkvenim skladbam (kot ga razkrivajo številne cerkvene muzikalije s sredine 19. stoletja, na primer v ptujski župnijski cerkvi), pa tudi praksa prirejanja cerkvenih del večjega formata za skromnejše, vendar »ne-ruralne« razmere v ljubljanski stolnici, ki med drugim hrani prav Maškove priredbe »praških maš« Vincenca Maška: »Für ein kleines Orchester als die Original / Partitur ausweiss / so wie auch mit mehreren Enderungen bearbeitet«, oziroma "für das kleine Orchester [...] neu instrumentiert und abgekürzt. / zum mehrseitigem Gebrauche [gesetzt] / für sämtliche Kirchen [...] wobey / die BlasInstrumente können ausgelassen werden [...] / von seinem Söhne Caspar Maschek« itn. ${ }^{10}$

Vse takšne bolj in manj posebne ter bolj in manj »razsežne«, pa tudi seveda bolj in manj pomembne ali vplivne prakse $\mathrm{v}$ gojenju cerkvene glasbe iz tistega obdobja na Slovenskem je treba razumeti kot relativno samostojne člene z razmeroma samosvojo vlogo v že tako precej razvejanem »zgodovinskem toku« te dejavnosti in jih obravnavati predvsem z vidika njihovega medsebojnega razmerja v strukturnem in »čisto-glasbenem « pogledu: tj. z vidika podobnosti in razlik med njimi, in ne le kot nekakšne odseve ali »emanacije« sloga dunajskega klasicizma kot njihovega »skupnega jedra«, okoli katerega

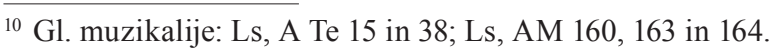


se ti členi nato razvrščajo samo kot manjvredni »epigoni dunajske klasike, ki so imeli vzor v Mozartu in še bolj v Josephu Haydnu«. ${ }^{11}$

Nekaj študij, ki preučujejo posamezne segmente cerkvene glasbene dejavnosti v Sloveniji od sredine 18. do prvih desetletij 19. stoletja in posegajo bolj na »drugo stran« te dejavnosti, je v zadnjih letih že bilo opravljeno. Med njimi velja posebej omeniti prispevek o frančiškanski zbirki cerkvenih skladb iz Brežic Matjaža Barba, ki je avtor tudi ene od doslej le dveh objavljenih monografij o življenju in delu vidnejših predstavnikov omenjene dejavnosti na naših tleh. Prva je monografija o G. Riharju, ki je izšla leta 2003 (njen avtor je Edo Škulj), druga pa o F. J. B. Dusíku iz leta 2009.

S cerkvenoglasbenim delovanjem frančiškanskih redovnikov pri nas v času 18. in 19. stoletja se podrobneje ukvarja še prispevek Darje Frelih iz leta 2005, deloma pa tudi razprava o podeželski glasbi v Sloveniji R. Škrjanca (dokončana leta 2008), ki po eni strani analizira odnos med različnimi deli cerkvenih opusov skladateljev, aktualnih na Slovenskem v tem obdobju, po drugi strani pa skuša ugotoviti ustrezen konceptualni okvir za zgodovinsko interpretacijo sakralne musice ruralis kot pomembnega dela glasbene dejavnosti na naših tleh v 18. in 19. stoletju.

Objava večjega števila monografij, kakršna je zlasti o Dusíku M. Barba - ki bi torej celoviteje predstavile življenje in delo prej omenjenih skladateljev ter hkrati kritično posegle v dozdajšnje védenje o tem (tako s ponovno preveritvijo že znanih »dejstev« in, če je mogoče, z razširitvijo obsega le-teh, kot tudi, vsaj ponekod, z vnovičnim premislekom o načinu njihove razlage) - je zagotovo še ena od potrebnejših nalog (domače) muzikologije za v prihodnje; ne samo zaradi potrebe po izboljšanju poznavanja zlasti odnosa med posameznimi deli in »stranmi« opusov skladateljev, pomembnih za domačo cerkveno glasbeno ustvarjalnost 18. in 19. stoletja, ${ }^{12}$ ki mora takšne monografije seveda nujno zanimati, temveč tudi zaradi potrebe po izboljšanju pregleda in sploh same védnosti o delu teh skladateljev, ki je še v veliki meri pomanjkljiva.

Prav izboljšanje celovitosti pregleda in poznavanja vsebine arhivskih fondov $\mathrm{v}$ Sloveniji, ki hranijo starejše muzikalije s cerkveno glasbo iz obdobja 18. in 19. stoletja, je bilo osnovni namen treh obsežnejših raziskav po letu 2000. Dve med njimi sta potekali pod vodstvom Metode Kokole kot raziskovalna projekta Muzikološkega inštituta ZRC SAZU z naslovom Glasbeni viri 16. do 18. stoletja s posebnim ozirom na slovenske primorske arhive in Cerkveni glasbeni fondi slovenskih obalnih mest. Njun cilj je bila med drugim arhivska ureditev in katalogiziranje vseh cerkvenih muzikalij iz tega obdobja, ki so v treh

${ }^{11}$ Prim. J. Höfler, nav. delo, str. 132.

${ }^{12}$ Nekaj prispevkov, na katere se lahko opre prihodnje raziskovanje odnosa med različnimi deli opusov dveh takšnih skladateljev (Dusika in Schwerdta), je že bilo objavljeno. Gre za sledeče prispevke: Marija Bergamo Značilnosti glasbenega gradiva, sintakse in strukturnega reda Simfonije v C-duru F. B. Dusíka kot kriterij slogovne opredelitve in vrednostne sodbe, Muzikološki zbornik 24 (1988); ista, Zwischen Serenade und Symphonie: Frantisek Josef Benedikt Dusik (1765-nach 1817), Off-Mozart: Glasbena kultura i mali majstori srednje Europe 1750-1820, Muzikološki zbornici 3, Zagreb, 1992); Andrej Rijavec, Simfonija v Es duru Leopolda Ferdinanda Schwerdta, Muzikološki zbornik 24 (1988); Arnold Feil, Die »Grande Serenade« von L. F. Schwerdt unter den Nachfolgekompositionen von Beethovens Septett op. 20. Zum Verhältnis Klassik-Klassizismus in der musikalischen Kompositionen nach 1800, Muzikološki zbornik 24 (1988). 
koprskih in dveh piranskih arhivih ter enem arhivu v Izoli. Popisano gradivo je deloma Že vključeno v elektronski register celotne starejše glasbene dediščine na Slovenskem in v RISM, tako kot še popisi muzikalij v arhivih Ljubljanske stolnice, Novomeškega kapitlja in knjižnici Frančiškanskega samostana v Novem mestu (v RISM še niso vključeni registri muzikalij cerkvene glasbe iz 18. in 19. stoletja, ki se hranijo v Frančiškanskem samostanu v Ljubljani, v mariborski stolnici, v cerkvi sv. Danijela v Celju, v knjižnici Petra Pavla Glavarja v Komendi in v arhivu Župnijskega urada sv. Jurija na Ptuju). Gradivo v arhivih slovenskih obalnih mest je zelo obsežno in terja še nadaljnje, zlasti bolj »vsebinsko « usmerjeno raziskovanje, ki bi denimo izčrpneje preučilo tudi razmerje med glasbo v cerkvah na Primorskem in drugod v Sloveniji (iz druge polovice 18. in začetka 19. stoletja), tj. zgodovinsko zelo indikativen odnos med dvema različnima tradicijama cerkvene glasbe na Slovenskem v tem času (italijansko oz. beneško in srednjeevropsko oz. avstrijsko), na kar prav tako opozarja že vsebina Höflerjevih Tokov.

Tretja raziskava je obsegala natančen pregled, dokumentiranje in repertoarno analizo vseh do zdaj znanih arhivskih zbirk s cerkveno glasbo 18. in 19. stoletja v »kontinentalnem« delu Slovenije (tj. devetih zbirk, ki so v Novem mestu, Celju, Mariboru, Ljubljani, Komendi in na Ptuju). Izhodišče raziskave so bile nekatere že objavljene informacijo o teh zbirkah, predvsem v člankih Janeza Höflerja, Danila Pokorna, Darje Koter in Tomaža Faganela, potekala pa je v okviru preliminarnih raziskav za preučitev odnosa med podeželsko in preostalo cerkveno glasbo pri nas iz tega obdobja, ki ga tematizira že omenjena razprava R. Škrjanca. Izsledki raziskave so za zdaj objavljeni le delno (leta 2005 in 2006 v De musica diserenda). Manjkata še objava drugega dela analize repertoarja cerkvenih skladb tujih skladateljev in objava celovite evidence cerkvenih skladb pri nas delujočih skladateljev, ki jih hranijo raziskane zbirke.

Poleg že omenjenih nalog, ki jih mora nadaljnje raziskovanje cerkvene glasbe v Sloveniji seveda čim bolj temeljito izpolniti, če želi »izslediti« vsaj zadostno količino »referenc«, potrebnih za pisanje »nove zgodovine glasbe« na Slovenskem (za obdobje 18. in 19. stoletja), so izdaje znanstvenih transkripcij skladb iz tega obdobja zagotovo tudi to, čemur se bo to raziskovanje moralo v prihodnje znatneje posvetiti. Širše dostopne in strokovno relevantne izdaje notnega gradiva s področja cerkvene glasbene ustvarjalnosti pri nas iz druge polovice 18. in začetka 19. stoletja so namreč za zdaj še redkost. Obsegajo le ves znani opus cerkvenih skladb J. F. Zupana ter po tri obsežnejše maše V. Wratnyja in L. F. Schwerdta, ki so vse izšle v zbirki Monumenta artis musicae Sloveniae med leti 1999 in 2006. Še neobjavljen pa ostaja revidirani prepis Dusíkove slovesne maše v C-duru, ki ga je pripravila Ana Pevec-Megušar (že leta 1996).

Na koncu tega zgoščenega pregleda stanja dosedanje raziskanosti, pa tudi razmisleka o načinih preteklih obravnav cerkvene glasbene dejavnosti pri nas v drugi polovici 18 . in na začetku 19. stoletja ter o nalogah, ki čakajo prihodnje raziskovanje te dejavnosti, je treba omeniti vsaj še dvoje: Prvo so priročne in že zato zelo koristne publikacije E. Škulja, izdane v zadnjem desetletju, kot sta Leksikon cerkvenih glasbenikov in zbornik največkrat uglasbenih bogoslužnih besedil (s komentarji in slovenskimi prevodi). Škulj je tudi avtor novejše (kumulativne) izdaje napevov v slovenskih cerkvenih pesmaricah 18. in zgodnjega 19. stoletja ter avtor številnih prispevkov s področja gradnje orgel za različne cerkvene ustanove na Slovenskem v preteklosti, ki pomembno dopolnjujejo poznavanje 
stanja cerkvene glasbe pri nas v času 18. in 19. stoletja $\mathrm{z}$ vidika strukture in deloma rabe glasbenega instrumentarija. Podobno velja za prispevke Darje Koter o glasbilarstvu na Slovenskem v tem obdobju.

Drugo so prispevki, ki poznavanje tega stanja dopolnjujejo še z vidika pedagoške glasbene dejavnosti različnih cerkvenih ustanov. Posebno zaslužna za sedanji celovitejši uvid v zgodovino glasbenega šolstva na Slovenskem (po letu 1790) je objava rezultatov Budkovičeve raziskave te dejavnosti iz leta 1992 (v prvem zvezku knjige Razvoj glasbenega šolstva na Slovenskem). Razjasnitev bolj vsebinskih vprašanj, ki se dotikajo sicer zelo razvejane tematike o preteklem poučevanju glasbe v Sloveniji (tudi pred letom 1790), je cilj raziskovalnega projekta Didaktični priročniki in glasbena vzgoja v 18. stoletju, ki poteka na Muzikološkem inštitutu ZRC SAZU in se ukvarja v prvi vrsti s frančiškansko glasbeno-pedagoško dejavnostjo pri nas v drugi polovici 18. stoletja kot konstitutivnim delom razmeroma posebne glasbene prakse frančiškanov v tem obdobju.

Bibliografija, ki sledi, je širši izbor objavljenih in deloma tudi neobjavljenih del, ki pomembneje prispevajo k poznavanju cerkvenoglasbene dejavnosti na Slovenskem v drugi polovici 18. in na začetku 19. stoletja in so nastala po letu 1950. Starejša podobna dela v ta seznam niso vključena. Izčrpnejši popis le-teh vsebujeta seznama literature v prvi in drugi knjigi Cvetkove Zgodovine glasbene umetnosti na Slovenskem iz let 1958 in 1959.

\section{Bibliografija}

Arbo, Alessandro, Dusík, Wrattni e la ricezione del Klassik musicale centroeuropeo a Gorizia nei primi decenni dell'Ottocento, Itinerari del Classicismo musicale. Trieste e la Mitteleuropa, ur. Ivano Cavallini, Trst 1992, str. 39-54.

Arbo, Alessandro, I fondi musicali dell'Archivio storico provinciale di Gorizia, Gorica 1994.

Arbo, Alessandro, Musicisti di frontiera. Le attività musicali a Gorizia del Medioevo al Novecento, Monografie storiche Goriziane 1, Gorica, Commune di Gorizia, 1998.

Bagarič, Alenka in Frelih, Darja, Starejše muzikalije v knjižnici in arhivu minoritskega samostana v Piranu, Sedem stoletij minoritskega samostana sv. Frančiška Asiškega v Piranu: 1301-2001, ur. France M. Dolinar in Marjan Vogrin, Piran, Slovenska minoritska provinca sv. Jožefa, 2001, str. 335-352.

Barbo, Matjaž, »Cantual« brežiškega frančiškanskega samostana, Brežiške študije 2010, ur. Jože Škofljanec (v tisku).

Barbo, Matjaž, František Josef Benedikt Dusik, Razprave FF, Ljubljana, Znanstvena založba Filozofske fakultete v Ljubljani, 2009.

Barbo, Matjaž, Prispevek k orisu življenja in dela F. J. B. Dusíka, Glasbeno-pedagoški zbornik Akademije za glasbo v Ljubljani 5 (2005), str. 53-68.

Beltram, Vlasta, Gardina, Helena in Koter, Darja, Musica aeterna est: glasbeno življenje v slovenskih obalnih mestih do 19. Stoletja, Koper, Pokrajinski muzej Koper, 2006.

Bizjak, Milko in Škulj, Edo, Orgle na Slovenskem, Ljubljana, Državna založba Slovenije, 1985.

Budkovič, Cvetko, Razvoj glasbenega šolstva na Slovenskem I. Od začetka 19. stoletja 
do nastanka konservatorija, Razprave FF, Ljubljana, Znanstveni inštitut Filozofske fakultete, 1992.

Budkovič, Cvetko, Začetki glasbenega šolstva v Ljubljani, Zbornik ob Jubileju Jožeta Sivca, ur. Jurij Snoj in Darja Frelih, Ljubljana, Muzikološki inštitut ZRC SAZU, 2000, str. 167-180.

Cvetko, Dragotin, Odmevi glasbene klasike na Slovenskem, Ljubljana, Državna založba Slovenije, 1955.

Cvetko, Dragotin, Odsev razsvetljenstva v glasbi na Slovenskem, Obdobje razsvetljenstva v slovenskem jeziku, književnosti in kulturi, Obdobja 1, Ljubljana 1980, str. 385-396.

Cvetko, Dragotin, Razvojne posebnosti glasbenega klasicizma na Slovenskem, Evropski glasbeni klasicizem in njegov odmev na Slovenskem, ur. Dragotin Cvetko in Pokorn Danilo, Ljubljana, SAZU, 1988, str. 5-12.

Cvetko, Dragotin, Slovenska glasba v evropskem okviru, Ljubljana, Slovenska matica, 1991.

Cvetko, Dragotin, Zgodovina glasbene umetnosti na Slovenskem 1, Ljubljana, Državna založba Slovenije, 1958.

Cvetko, Dragotin, Zgodovina glasbene umetnosti na Slovenskem 2, Ljubljana, Državna založba Slovenije, 1959.

Cvetko, Dragotin, Zupan - zadnji mojster slovenskega glasbenega baroka, Zbornik Akademije za glasbo 2, Ljubljana 1965, str. 17-26.

Faganel, Tomaž, Glasbeni repertoar na Slovenskem v 18. stoletju in v prvi polovici 19. stoletja, Academia Philharmonicorum Labacensium 1701-2001, ur. Ivan Klemenčič, Ljubljana, Založba ZRC, 2004, str. 119-129.

Faganel, Tomaž, Nekaj vprašanj ob izvajanju Riharjevih skladb, Festival slovenske cerkvene glasbe. Zbornik kolokvijev, ur. Edo Škulj, Knjižnica Cerkvenega glasbenika, Zbirka 5, Knjižna zbirka 17, Ljubljana, Slovensko Cecilijino društvo, Družina, 2002, str. 13-22.

Flotzinger, Rudolf, Der Sonderfall Wiener Klassik - Zur Beurteilung ihrer Rezeption in Slowenien, Evropski glasbeni klasicizem in njegov odmev na Slovenskem, ur. Dragotin Cvetko in Danilo Pokorn, Ljubljana, SAZU, 1988, str. 13-24.

Frelih, Darja, Glasba 18. in 19. stoletja v ohranjenih rokopisih ljubljanskih frančiškanov, De musica disserenda 1/1-2 (2005), str. 61-74.

Höfler, Janez, Glasbena kapela ljubljanske stolnice 1800-1810, Muzikološki zbornik 17/2 (1981), str. 7-22.

Höfler, Janez in Klemenčič, Ivan, Glasbeni rokopisi in tiski na Slovenskem do leta 1800, Ljubljana 1967.

Höfler, Janez, Glasbenozgodovinske najdbe XVIII. in XIX. stoletja v Novem mestu, Kronika 15/3 (1967), str. 135-148.

Höfler, Janez, Slovenska cerkvena pesem v 18. stoletju. Tipološki prikaz njenega glasbenega stavka, Slovenska akademija znanosti in umetnosti, Razred za zgodovinske in družbene vede, Razprave IX/2, Ljubljana, Slovenska akademija znanosti in umetnosti, 1975.

Höfler, Janez, Tokovi glasbene kulture na Slovenskem, Ljubljana, Mladinska knjiga, 1970. Klemenčič, Ivan, Slogovni razvoj glasbenega baroka na Slovenskem, Glasbeni barok na 
Slovenskem in evropska glasba, ur. Ivan Klemenčič, Ljubljana, Založba ZRC, 1997, str. 27-41.

Kokole, Metoda, Bagarič, Alenka in Frelih, Darja, Glasbena dediščina slovenskih obalnih mest do 19. Stoletja. Vodnik po razstavi, Ljubljana, Založba ZRC, 2003.

Koter, Darja, Glasba za pihala, izdelovanje glasbil in instrumentalna dediščina na Slovenskem v evropskem okviru, Zbornik Pokrajinskega muzeja Ptuj 1, Ptuj 2003, str. 126-137.

Koter, Darja, Glasbeni motivi v likovni dediščini od severne Istre do Vremske doline, Koper, Pokrajinski muzej Koper, 2008.

Koter, Darja, Glasbilarstvo na Slovenskem, Maribor, Obzorja, 2004.

Koter, Darja, Izdelovalci glasbil na Slovenskem, Muzikološki zbornik 39/1-2 (2003), str. 123-154.

Koter, Darja, Izdelovalci pihal na Slovenskem in njihova dediščina, Muzikološki zbornik 35 (1999), str. 147-166.

Koter, Darja, Muzikalije ptujske cerkve sv. Jurija, Ptujska župnijska cerkev sv. Jurija. Zbornik znanstvenega simpozija ob praznovanju 1150. obletnice posvetitve mestne cerkve in 850. obletnice »Konradove cerkve«, ur. Slavko Kranjc, Ptuj, Samostan sv. Viktorina, 1998, str. 260-279.

Koter, Darja, Pojav in razvoj delavnic glasbil ob glasbenem šolstvu na Slovenskem, Ljubljana 1998 (Univerza v Ljubljani, doktorska disertacija).

Krstulović, Zoran, Kompozicijski stavek v svečanih mašah Leopolda Ferdinanda Schwerdta, Muzikološki zbornik 29 (1993), str. 21-32.

Krstulović, Zoran, Masses by Leopold Ferdinand Schwerdt: Structures of musical periphery, Off-Mozart: Glasbena kultura i mali majstori srednje Europe 1750-1820, Muzikološki zbornici 3, Zagreb 1992, str. 85-90.

Krstulović, Zoran, Značilnosti kompozicijskega stavka L. F. Schwerdta s posebnim ozirom na njegove maše, Ljubljana 1998 (Univerza v Ljubljani, magistrsko delo).

Kuret, Primož, Haydnova vokalno-instrumentalna dela na programih Filharmonične družbe v Ljubljani, Muzikološke razprave. In memoriam Danilo Pokorn, ur. Nataša Cigoj Krstulović, Tomaž Faganel, Metoda Kokole, Ljubljana, Založba ZRC, Muzikološki inštitut ZRC SAZU, 2004, str. 67-86.

Nagode, Aleš, Die Rolle des mitteleuropäischen Raumes in der Entwicklung der slowenischen Kirchenmusik des 19. Jahrhunderts, Muzikološki zbornik 40/1-2 (2004), str. 257-266.

Nagode, Aleš, Slavnostne maše Venčeslava Wratnyja, Muzikološki zbornik 32 (1996), str. 51-60.

Nagode, Aleš, Šest latinskih maš Venčeslava Wratnyja, Ljubljana 1994 (Univerza v Ljubljani, Filozofska fakulteta, magistrsko delo).

Pevec-Megušar, Ana, Franc Benedikt Dussik. Slovesna maša v C-duru, Ljubljana 1996 (Univerza v Ljubljani, Oddelek za muzikologijo Filozofske fakultete, diplomsko delo). Pokorn, Danilo, Amandus Ivančič (Ivanschiz) - Prispevek k poznavanju glasbe zgodnjega klasicizma, Evropski glasbeni klasicizem in njegov odmev na Slovenskem, ur. Dragotin Cvetko in Pokorn Danilo, Ljubljana, SAZU, 1988, str. 63-73. 
Pokorn, Danilo, Glasbena zbirka opatijske cerkve sv. Danijela v Celju, Muzikološki zbornik 25 (1989), str. 107-120.

Pokorn, Danilo, Slovenski glasbenik Matej Babnik v luči novih odkritij, Muzikološke razprave, Ljubljana, Muzikološki inštitut ZRC SAZU, 1993, str. 89-103.

Pokorn, Danilo, Slovenski skladatelj Jakob Zupan, Radovi Zavoda za znanstveni rad HAZU Varaždin 4-5, Varaždin 1990-1991, str. 177-181.

Radole, Giuseppe, La musica a Capodistria, Trst, Centro studi storico-religiosi FriuliVenezeia Giulia, 1990.

Schwerdt, Leopold Ferdinand, Missa pastorale op. 93, ur. Zoran Krstulović, Monumenta artis musicae Sloveniae 49, Ljubljana, Muzikološki inštitut ZRC SAZU, 2006.

Schwerdt, Leopold Ferdinand, Missa pro Resurrectione D. N. J. C. in Es, ur. Zoran Krstulović, Monumenta artis musicae Sloveniae 45, Ljubljana, Muzikološki inštitut ZRC SAZU, 2003.

Schwerdt, Leopold Ferdinand, Missa St. Floriani in D, ur. Zoran Krstulović, Monumenta artis musicae Sloveniae 43, Ljubljana, Muzikološki inštitut ZRC SAZU, 2002.

Smolik, Marijan, Franciscus Josephus Thallmainer 1698-1768, Muzikološki zbornik 3 (1968), str. 47-53.

Snížková, Jitka, František Josef Benedikt Dusík (Cormundi), Evropski glasbeni klasicizem in njegov odmev na Slovenskem, ur. Dragotin Cvetko in Pokorn Danilo, Ljubljana, SAZU, 1988, str. 85-89.

Snížková, Jitka, František Josef Benedikt Dusík, Muzikološki zbornik 26 (1990), str. 29-36.

Škrjanc, Radovan, Novo o Akademskem združenju sv. Cecilije v Kamniku, Muzikološki zbornik 37 (2001), str. 51-66.

Škrjanc, Radovan, Novo v poznavanju repertoarja starejših muzikalij cerkvene glasbe v Sloveniji, De musica disserenda 4/2 (2008), str. 87-104.

Škrjanc, Radovan, Prispevek k dataciji rokopisov skladb Jakoba Frančiška Zupana, Muzikološki zbornik 34 (1998), str. 35-68.

Škrjanc, Radovan, Prispevek k poznavanju repertoarja starejših muzikalij cerkvene glasbe v Sloveniji [1. del], De musica disserenda 1/1-2 (2005), str. 141-165.

Škrjanc, Radovan, Prispevek k poznavanju repertoarja starejših muzikalij cerkvene glasbe v Sloveniji [2. del], De musica disserenda 2/1 (2006), str. 30-60.

Škrjanc, Radovan, »Stylus rusticanu« v cerkveni glasbi na Slovenskem od sredine 18. do sredine 19. stoletja, Ljubljana 2008 (Univerza v Ljubljani, Filozofska fakulteta, doktorska disertacija).

Škrjanc, Radovan, Vprašanje sloga v skladbah Jakoba Frančiška Zupana, Ljubljana 1999 (Univerza v Ljubljani, Filozofska fakulteta, magistrsko delo).

Škrjanc, Radovan, Vprašanje slogovne opredelitve skladb - poskus obravnave na primeru cerkvenih del Jakoba F. Zupana, Muzikološki zbornik 36 (2000), str. 65-72.

Škulj, Edo, Beneške orgle na Slovenskem, Glasbeni barok na Slovenskem in evropska glasba, ur. Ivan Klemenčič, Ljubljana, Založba ZRC, 1997, str. 203-223.

Škulj, Edo, Cerkveni ljudski napevi. II. Starejši katoliški napevi, Ljubljana, Družina, 2001. Škulj, Edo, Goršičeva orglarska delavnica, Ljubljana, Družina, 2004.

Škulj, Edo, Gregor Rihar (1796-1863), Ljubljana, Družina, 2003. 
Škulj, Edo, Hubertus von Kerssenbrock, Knjižnica Cerkvenega glasbenika, Nove in obnovljene orgle 1, Ljubljana, Družina, Cerkveni glasbenik, 1990.

Škulj, Edo, Leksikon cerkvenih glasbenikov, Ljubljana, Družina, 2005.

Škulj, Edo (ur.), Maškov zbornik, Knjižnica cerkvenega glasbenika, Zbirka 5, Knjižna zbirka 16, Ljubljana, Družina, 2002.

Škulj, Edo, Milavčeva orglarska delavnica, Škocjan pri Turjaku, Župnija Škocjan pri Turjaku, 2007.

Škulj, Edo, Orglarji in orgle v samostanski cerkvi, Sedem stoletij minoritskega samostana sv. Frančiška Asiškega v Piranu: 1301-2001, ur. France M. Dolinar in Marjan Vogrin, Piran, Slovenska minoritska provinca sv. Jožefa, 2001, str. 315-334.

Škulj, Edo, Orgle in organisti v sedanji ljubljanski stolnici, Ljubljana, Družina, 2005.

Škulj, Edo, Orgle na Slovenskem v dobi klasicizma, Evropski glasbeni klasicizem in njegov odmev na Slovenskem, ur. Dragotin Cvetko in Danilo Pokorn, Ljubljana, SAZU, 1988, str. 97-106.

Škulj, Edo, Orgle v ljubljanski stolnici, Ljubljana, Muzikološki inštitut ZRC SAZU, Ljubljana 1989.

Škulj, Edo, Orgle v minoritskih cerkvah, Ptujska župnijska cerkev sv. Jurija. Zbornik znanstvenega simpozija ob praznovanju 1150. obletnice posvetitve mestne cerkve in 850. obletnice »Konradove cerkve«, ur. Slavko Kranjc, Ptuj, Samostan sv. Viktorina, 1998, str. 280-299.

Škulj, Edo, Orgle v uršulinski cerkvi in glasbena ustvarjalnost uršulink, Tristo let ljubljanskih uršulink. Zgodovina samostana, njegovih šol in kulturnih dejavnosti, ur. Marija Jasna Kogoj, Ljubljana, Družina, 2002, str. 223-242.

Škulj, Edo, Textus liturgici / Bogoslužna besedila, Ljubljana, Družina, 2002.

Špendal, Manca, Fond klasicističnih skladb v mariborskem stolnem arhivu, Evropski glasbeni klasicizem in njegov odmev na Slovenskem, ur. Dragotin Cvetko in Danilo Pokorn Danilo, Ljubljana, SAZU, 1988, str. 115-122.

Zupan, Jakob Frančišek, Arije in dueti, ur. Radovan Škrjanc, Monumenta artis musicae Sloveniae 36, Ljubljana, Muzikološki inštitut ZRC SAZU, 1999.

Zupan, Jakob Frančišek, Te Deum laudamus, Lythaniae in G, Missa ex C, Missa in B, ur. Radovan Škrjanc, Monumenta artis musicae Sloveniae 38, Ljubljana, Muzikološki inštitut ZRC SAZU, 2006.

Wratny, Venceslav, Missa in A, ur. Aleš Nagode, Monumenta artis musicae Sloveniae 39, Ljubljana, Muzikološki inštitut ZRC SAZU, 2000.

Wratny, Venceslav, Missa in B, ur. Aleš Nagode, Monumenta artis musicae Sloveniae 37, Ljubljana, Muzikološki inštitut ZRC SAZU, 2000.

Wratny, Venceslav, Missa in G, ur. Aleš Nagode, Monumenta artis musicae Sloveniae 41, Ljubljana, Muzikološki inštitut ZRC SAZU, 2001. 


\title{
THE PRESENT STATE OF RESEARCH ON SACRED MUSIC IN SLOVENIA FROM THE MID-EIGHTEENTH TO THE BEGINNING OF THE NINETEENTH CENTURY
}

\begin{abstract}
Summary
The extent of research on sacred music activities in Slovenia from the second half of the eighteenth century to the beginning of nineteenth century is relatively broad, at least in comparison with the rather narrow range of investigations that have been undertaken so far with regard to other segments of musical life in Slovenia from the same time period. The reason partly lies in the treatment of Slovenia's musical past by conceptually dividing history into style periods such as Baroque and Classical, on the principle of generalization as one of the main maxims in organizing the details from that past into relatively comprehensive historical narratives (using the "logic of Zeitgeist"). At the same time and following the same principle, this also allows the overall musical legacy in Slovenia to be historically outlined (e.g., from Baroque to Classicism) simply by reducing it to a substantially truncated number of historical events that happened only in the region of the former province of Carniola or even just in the current capital of Slovenia (Ljubljana). This kind of geographically-based "centrism" or "reductionism" in music historiography occurs most evidently even in Zgodovina glasbene umetnosti na Slovenskem (The History of Music in Slovenia), written by Dragotin Cvetko in the 1950s. It is also echoed in some subsequent treatises on eighteenth- and nineteenth-century music in Slovenia that exclude a significant portion of information relevant to the history of this music. Primarily this is information concerning past musical activities cultivated in some Slovenian centers that were no less important than Ljubljana (e.g. Koper, Novo Mesto, Maribor, Ptuj, Celje, etc.) and that is essential not only for more complete and accurate knowledge of various sacred music traditions that existed at that time in Slovenia but also for a more profound insight into other segments of musical life from that period that belong to the symphonic, chamber, and piano music genres or to music pedagogy. Surprisingly, an important contribution in this regard can be found in Janez Höfler's Tokovi glasbene kulture na Slovenskem od začetkov do 19. stoletja (Developments in musical culture in Slovenia from its beginnings to the nineteenth century), published in 1970. This volume also offers - in accordance with the trends in music historiography then valid, and especially with the "cultural history" of music - some new ideas for future music history writing in general and gives a solid basis for a more detailed as well as integral inquiry into sacred music in Slovenia from the eighteenth and nineteenth centuries in particular, which is certainly needed in the future. This inquiry should be pursued from several different angles. Among these the most important seems to be research directed precisely toward the study of some markedly specific musical practices that Höfler places within the "other [i.e., less skilled or less artistic] side of sacred music" in the eighteenth and nineteenth centuries, such as "Franciscan music" practices and the music assigned to rural churches, which have been largely neglected in Slovenian musicology so far, in spite of the leading position they occupied in sacred musical life in Slovenia at that time. No less important a task for the future investigation of this life is also to fill in the gaps in knowledge of the contents of
\end{abstract}


archives in Slovenia holding sacred compositions from the eighteenth and nineteenth centuries, as well as preparing critical scholarly editions of at least the most important examples of such compositions as the starting point for their future comparative analysis. 